ks. Marek Kluz

WYDZIAE TEOLOGICZNY SEKCJA W TARNOWIE

UNIWERSYTETU PAPIESKIEGO JANA PAW

ks. mgr lic. Artur Sylwester Słomka

PARAFIA ŚW. TERESY OD DZIECIĄTKA JEZUS W GDAŃSKU

\title{
Małżénstwo \\ jako wyraz pełnej realizacji miłości między mężczyzną a kobietą
}

\section{Wstęp}

W dobie jawnego kwestionowania trwałości i sensu instytucji małżeńskiej rodzi się wielka potrzeba i obowiązek jej ratowania. Nie wystarcząjednak same słowa, za nimi muszą iść czyny. Dlatego przykład zdrowych i prawdziwie miłujących się małżeństw winien na trwałe wpisać się w rzeczywistość obecnej kultury. Bardzo ważne jest, aby młode pokolenie było wychowywane na zdrowych wzorcach poprzez przykład swoich najbliższych. Małżeństwo pochodzi od Boga i jest nierozerwalną wspólnotą dwu osób różnej płci, dającą im mocą prawa naturalnego moralne uprawnienia i obowiązki do osobowego rozwoju w miłości prokreatywnej. Stąd wynika, że małżeństwo jest wspólnotą w swej strukturze bardzo prostą, ponieważ w jej skład wchodzą tylko dwie równorzędne i równoprawne osoby ludzkie. Jednocześnie jest najmniejszą społecznością autonomiczną, dlatego że ingerencja w wewnętrzne sprawy dwóch osób tak żyjących jest niemoralna. Jest również społecznością niedoskonałą, ponieważ samo 
zmierza do dopełnienia się w rodzinie, która jest naturalnym jego przedłużeniem ${ }^{1}$.

Miłość nie jest dana człowiekowi jako coś doskonałego. Każdy człowiek musi ją świadomie rozwijać i pogłębiać ${ }^{2}$. Dokumenty Kościoła ukazują małżeństwo jako wezwanie i zobowiązanie do miłości ${ }^{3}$. Temat miłości małżeńskiej jako wezwania i zadania akcentuje wyraźnie adhortacja apostolska Familiaris consortio Jana Pawła II ${ }^{4}$, jak również Katechizm Kościoła Katolickiego5.

\section{Dobra i cele małżeństwa chrześcijańskiego}

W odniesieniu do instytucji małżeństwa pytanie o cel małżeństwa jest jednocześnie pytaniem: po co? Samo słowo „cel” może być rozumiane jako równoważne słowom „rezultat”, „kres” czy „meta” lub jako synonim słowa „tendencja”, czyli „ukierunkowanie na”. Cel w małżeństwie jest rozumiany w tym drugim znaczeniu jako przyczyna celowa małżeństwa, która determinuje jego naturę. Małżeństwo ze względu na swój charakter jest podporządkowane dobru małżonków oraz przekazywaniu i wychowywaniu życia ${ }^{6}$. Jan Paweł II podkreśla, że z miłości Bóg stworzył człowieka na swoje podobieństwo i swój obraz, powołując go do istnienia, powołał

1 Por. W. Gasidło, Z zagadnień etyki matżeńskiej i rodzinnej, Kraków 1990, s. 64-65.

2 Por. A. Kokoszka, Moralność życia matżeńskiego, Tarnów 1997, s. 128.

3 Por. Sobór Watykański II, Konstytucja Gaudium et spes [dalej: KDK], 49, 52.

4 Por. Jan Paweł II, Adhortacja apostolska Familiaris consortio [dalej: FC], 19.

5 Por. KKK 2360-2379.

6 Por. A. Sarmiento, Małżeństwo chrześcijańskie. Podręcznik teologii matżeństwa $i$ rodziny, Kraków 2002, s. 325. 
również $\mathrm{w}$ tym momencie do miłości ${ }^{7}$. Na tym fundamencie pojawiły się pewne cele. Pierwszy, małżeństwo i miłość małżeńska oraz jej specyficzny akt małżeński, są ukierunkowane ze swej natury na zrodzenie i wychowanie potomstwa. Natomiast drugi cel małżeństwa i miłości małżeńskiej oraz jego specyficzny akt małżeński ukierunkowane są ze swej natury na dobro i wzajemną pomoc małżonków. Wzajemna pomoc i rodzicielstwo wraz z wychowaniem dzieci są małżeństwem ukierunkowanym na ów podwójny cel bądź celowość ${ }^{8}$.

Celowość małżeństwa z perspektywy przyczynowości bardzo wyraźnie ukazuje św. Tomasz z Akwinu. Uściśla on rozumienie natury i istoty małżeństwa. Mówi on o celach małżeństwa, które dzieli na istotne i przypadłościowe. Bez tych pierwszych związek małżeński nie może istnieć. Należą do nich rodzicielstwo oraz wzajemna pomoc małżonków. Natomiast jeżeli chodzi o cele przypadłościowe, to małżeństwo może bez nich istnieć. To te, które małżonkowie chcą podjąć z własnej woli`. Akwinata wymienia cele istotne: pierwszorzędne, drugorzędne i trzeciorzędne. Do celów pierwszorzędnych zalicza zrodzenie i wychowanie potomstwa, do drugorzędnych wierność i dobro rodziców, natomiast trzeciorzędne to lekarstwo na pożądliwość. Nie oznacza to jednak, że św. Tomasz przedstawił pojęcie prokreacji jako jedyne uzasadnienie przyjemności seksualnej w małżeństwie. To stwierdzenie, że prokreacja i zwrot debitum niejako uwalniają partnerów z grzechu powszedniego $\mathrm{w}$ rozkoszy seksualnej, jest podane w znacznie delikatniejszym kontekście.

7 Por. FC 11.

8 Por. A. Sarmiento, Małżeństwo chrześcijańskie..., dz. cyt., s. 325.

9 Por. A. Sarmiento, Małżéstwo chrześcijańskie..., dz. cyt., s. 328. 
Święty Tomasz wskazywał na odróżnienie erotyzmu będącego egoistycznym szukaniem zadowolenia od wzajemnego zaspokojenia, które jest znakiem zjednoczenia partnerów duszą i ciałem. Patrząc na to drugie uzasadnienie, można dostrzec miłość jako tę, która jest właściwym motywem stosunków płciowych ${ }^{10}$. Szczególnym celem związku małżeńskiego jest wzajemna pomoc i wierność, a szczególnym celem związku małżeńskiego między ochrzczonymi jest sakrament. Ten ostatni ma wyjątkowy wymiar ze względu na to, że oznacza zjednoczenie Kościoła z Chrystusem. Zrodzenie i wychowanie potomstwa odpowiada człowiekowi jako jestestwu należącemu do tego samego rodzaju, co zwierzęta. Wierność odpowiada człowiekowi jako człowiekowi, a sakramentalność jako chrześcijaninowi. Wśród tych celów istnieją pewna relacja i porządek. Święty Tomasz używa terminologii, która nie jest jednorodna, a hierarchizacja celów nie jest sztywna. Zarówno cele, jak i dobra są używane zamiennie. Mimo to rozróżnia jasno cel główny od pozostałych celów, a co ważne, nie przeciwstawia ich sobie.

W połowie lat sześćdziesiątych wydano podręcznik teologii dogmatycznej Ottona Filka Dogmatyka, w którym można przeczytać: „Pierwszym celem małżeństwa jest zrodzenie i wychowanie potomstwa. Celem drugorzędnym jest wzajemna pomoc i zgodne z zasadami moralnymi zaspokajanie popędu płciowego". Autor, używając takiej interpretacji małżeństwa, być może powołuje się na długą tradycję, która sięga epoki starożytnej i, jak się wydawało, miała podstawy biblijne w opisie stworze-

10 Por. Kościót w świecie wspótczesnym. Nauczanie spoteczne Kościoła w świetle Soboru Watykańskiego II, red. R. Charles, D. Maclaren, przeł. J. Grosfeld, Poznań 1995, s. 151. 
nia ${ }^{11}$. Tradycyjna perspektywa etyki katolickiej szczególnie w okresie międzywojennym uległa całkowitemu odwróceniu. Podstawowy sens i cel małżeństwa wyznacza miłość i osobowe dopełnienie się małżonków. Za wyjściowy punkt należy obrać tylko jeden cel złożony z dwóch podstawowych elementów. Jest to dopełnienie się i rozwój osobowy małżonków, który zawiera w sobie doskonalenie się ich w miłości ukierunkowanej i wyrażonej w płodności. Nie można pojąć miłości i życiowej wspólnoty małżonków w oderwaniu od posiadania potomstwa. Godność miłości małżeńskiej wyraża seksualne dopełnienie się w jedno, gdzie punktem docelowym jest prokreacja. Owa prokreacja staje się procesem w pełni ludzkim, jeżeli odbywa się w klimacie prawdziwej wspólnej, małżeńskiej miłości. Małżeństwo, realizując swój cel w prokreacji, jednocześnie realizuje wartość miłości, podobnie jak miłość pociąga za sobą ukierunkowanie się małżonków na prokreację. W taki sposób cel małżeństwa umieszcza swe elementy składowe na tym samym poziomie moralnych wartości ${ }^{12}$. Mimo że prokreacja nie jest jedynym celem małżeństwa, jest sprawą wielkiej wagi. Małżonkowie, którzy bez własnej winy nie mogą mieć dzieci, nie muszą całkowicie pozbawiać wspólnoty małżeńskiej sensu płodności, ponieważ mogłoby to niekorzystnie wpłynąć na ich wspólnotę miłości. W takim związku jest możliwe odkrycie płodności duchowej. Płodność miłości w małżeństwie nie ogranicza sięjedynie do rodzenia własnych dzieci, lecz może się wyrażać poprzez adopcję $e^{13}$.

11 Por. A. Laun, Wspótczesne zagadnienia teologii moralnej. Teologia moralna. Zagadnienia szczegótowe, tłum. W. Szymona, Kraków 2002, s. 53.

12 Por. W. Gasidło, Z zagadnień etyki małżeńskiej i rodzinnej..., dz. cyt., s. 6465.

13 Por. S. Olejnik, Teologia moralna życia społecznego, Włocławek 2000, s. 305. 
Z obiektywnego punktu widzenia cel pierwszorzędny i specyficzny jest jeden, wyrażający się w rodzicielstwie i wychowaniu potomstwa. Drugorzędnym celem wynikającym z instytucji małżeństwa, a uzupełniającym pierwszy, jest wzajemna pomoc małżonków. Jednakże z perspektywy subiektywnej nic nie uniemożliwia faktu, aby wzajemna pomoc i doskonalenie się były celem pierwszym i głównym. Wraz z tym rozróżnieniem jest gwarantowany obiektywny charakter i ontologiczny prymat rodzicielstwa oraz wychowania dzieci, mimo że zmieniałyby się motywy, dla których zawierane jest małżeństwo. Nie jest sprzeczne, że dziecko może być celem głównym, obiektywnym i naturalnym małżeństwa, jak również celem pośrednim, subiektywnym i psychologicznym. Ta myśl ma swoją podstawę u św. Tomasza, choć jest wyrażana w innych słowach ${ }^{14}$.

\section{Ukierunkowanie małżeństwa na dobro małżonków}

Bóg powołał do istnienia instytucję małżeństwa, włączając ją w porządek stwórczy i zbawczy. Jest ono znakiem przymierza z Bogiem oraz obrazem życia Trójcy Świętej. Sakrament małżeństwa wprowadza małżonków w Boże źródło miłości. Małżeństwo i wypływająca z niego rodzina stają się wspólnym udziałem poświęconych sobie mężczyzny i kobiety. Akty małżeńskie mają swoją szczególną wartość, jeżeli chodzi o dążenie do wspólnego dobra. Małżonkowie dzielą wszystko między sobą w jedności i nierozerwalności oraz otwartości na płodnośćc ${ }^{15}$.

14 Por. A. Sarmiento, Małżeństwo chrześcijańskie..., dz. cyt., s. 331.

15 Por. S. Kowalczyk, Małżeństwo, [w:] Katolicyzm A-Z, red. Z. Pawlak, Poznań 1989, s. 248-250. 
Jedną z racji tworzących instytucję małżeństwa jest to, że ma być ramą dla małżonków. Małżeństwo poddaje się temu celowi z samej swej natury, zgodnie z wolą Boga od momentu stworzenia. Dlatego istotnymi i nierozerwalnymi przymiotami małżeństwa są jedność i nierozerwalność. Jednocześnie wraz z przyjęciem sakramentu małżeństwa związek ten zostaje wyniesiony i wprowadzony do porządku łaski, który zachowując w pełni wszystkie wymagania, przemienił się w prawdziwy i rzeczywisty obraz związku Chrystusa z Kościołem. Tego dobra małżonków jako celu małżeństwa nie utożsamia się z wzajemną pomocą ani z miłością małżeńską. Są to jednak wymiary tej samej rzeczywistości, które wzajemnie się na siebie nakładają. Miłość małżeńska jest wyrazem wzajemnej pomocy i do niej prowadzi. Zarówno jedna, jak i druga rzeczywistość pomagają w realizacji dobra małżonków. Najbardziej pełnym wyrazem wzajemnej pomocy jest wierność małżeńska ${ }^{16}$. Wierność oznacza stałość w dochowywaniu danego słowa, a sakrament małżeństwa wprowadza mężczyznę i kobietę w wierność Chrystusa wobec Jego Kościoła ${ }^{17}$. Ta wzajemna pomoc może być rozumiana $\mathrm{w}$ szerokim znaczeniu jako małżeństwo przeżywane i realizowane we wspólnocie życia i miłości. Wkracza tu również komplementarność niezbędna do zrodzenia potomstwa, która jest urzeczywistnianiem egzystencjalnym małżeństwa. Natomiast we właściwym znaczeniu ta pomoc wskazuje na komunikację dóbr i darów właściwych kobiecości i męskości w celu wzajemnego doskonalenia się, które może urzeczywistniać się tylko w małżeństwie

16 Por. A. Sarmiento, Matżeństwo chrześcijańskie..., dz. cyt., s. 337-338.

17 Por KKK 2365. 
jako wspólnocie. Jej rdzeniem jest obopólny dar, jaki dał początek małżeństwu ${ }^{18}$.

Bardzo wymowne są słowa wyjęte z Biblii: „Nie jest dobrze, aby mężczyzna był sam” (Rdz 2, 18). Nie chodzi tu właściwie o samotność biologiczną mężczyzny, jako że mężczyzna sam nie jest zdolny do zrodzenia potomstwa. Mowa jest tu o samotności w ogóle, bo do pełni pojęcia "człowiek" należą mężczyzna i kobieta. Kobieta stanowi dla mężczyzny pomoc. Pomoc, której nie znajdzie w całym świecie żywym. Pomoc nie jest rozumiana w sensie biologicznym jako współuczestniczenie w zrodzeniu potomstwa, ale również w sensie psychicznym i osobowym. To przez kobietę mężczyzna staje się tym, kim jest, i odwrotnie ${ }^{19}$.

Jedność dwojga jest ukierunkowana tak, by móc służyć osobistej realizacji małżonka lub małżonki. Relacja zachodząca między małżonkami w jedności jest wzajemna, tzn. że dobro drugiego jest wspólne, a małżeństwo podporządkowuje się i ukierunkowuje ku celowi, którym jest wzajemna komplementarność obojga, czyli służenie jedno drugiemu oraz wzajemna pomoc ${ }^{20}$. Związek małżeński, który jest budowany na miłości, prowadzi do jedności, która jest najściślejszym przejawem wspólnoty na ziemi. Jedność jednak nie usuwa osobowych różnic, jakie istnieją między mężczyzną a kobietą. Czasami w nawet najlepiej dobranym małżeństwie nie dochodzi do zniesienia wszystkich różnic. Pomijając ten fakt, jedność małżeńska polega na wzajemnym uzupełnianiu się małżonków. Stąd okre-

18 Por. A. Sarmiento, Matżeństwo chrześcijańskie..., dz. cyt., s. 338.

19 Por. Przygotowanie do małżenstwa, red. W. Szewczyk, Warszawa 1997, s. 93.

20 Por. A. Sarmiento, Malżeństwo chrześcijańskie..., dz. cyt., s. 338. 
ślenie „wzajemna pomoc”. Natomiast inne są zadania obu stron, ale mimo to równa jednak ich wzajemna odpowiedzialność za wspólne dobro małżeństwa. Szczególnie odpowiedzialni są za miłość wzajemną, za jej pielęgnowanie i rozwijanie. W ten sposób małżonkowie są równomiernie obciążeni troską o wspólne dobro ich związku ${ }^{21}$. Wzajemna pomoc małżonków, a co za tym idzie dobro małżonków, jest właściwym celem małżeństwa. Istnienie wzajemnej pomocy jest jakąś racją bytu małżonków. Jest celem złączonym z innymi, czyli takim, że jeśliby odłączyć go od pozostałych, narażone zostaną wszystkie inne. Wzajemna pomoc nie jest tożsama z rodzicielstwem, ale jest tak z nim związana, że respektowanie tej relacji jest jednym z kryteriów autentyczności w poszukiwaniu dobra małżonków jako celu małżeństwa ${ }^{22}$.

Wspólnota małżeńska we właściwy sobie sposób jest rzeczywistym znakiem zbawienia. Małżonkowie, którzy zostali zaślubieni, uczestniczą w związku we dwoje, jako para, do tego stopnia, że pierwszym i bezpośrednim skutkiem małżeństwa jest chrześcijańska więź małżeńska, komunia dwojga jako typowo chrześcijańska, ponieważ przedstawia tajemnicę Wcielenia Chrystusa i Jego Przymierza ${ }^{23}$. Dlatego wspólnota tych osób zaślubionych sobie jest zwana komunią osób. Komunia to coś więcej niż wspólnota, to po m o c płynąca poniekąd z faktu zaistnienia osoby obok osoby ${ }^{24}$.

Magisterium Kościoła wyraźnie potwierdza poddanie małżeństwa przekazywaniu życia, czyli rodzicielstwu i wychowaniu dzieci,

21 Por. A. Kokoszka, Moralność życia małżeńskiego, dz. cyt., s. 148-149.

22 Por. A. Sarmiento, Matżeństwo chrześcijańskie..., dz. cyt., s. 338.

23 Por. FC 13.

24 Por. Przygotowanie do małżeństwa, dz. cyt., s. 93. 
głosi jednocześnie konieczność nadania aspektu wzajemnej pomocy całego należnego jej znaczenia ${ }^{25}$. Potwierdzenie tej celowości pojawia się w tekście Soboru Watykańskiego II: „Przez najściślejsze zespolenie osób i działań świadczą sobie wzajemnie pomoc i posługę oraz doświadczają sensu swej jedności i osiągają ją w coraz pełniejszej mierze ${ }^{26}$. Małżeństwo jednak nie jest ustanowione wyłącznie dla rodzenia potomstwa; sama, bowiem natura nierozerwalnego związku między dwoma osobami oraz dobro potomstwa wymagają, aby wzajemna miłość małżonków odpowiednio się wyrażała, aby się rozwijała i dojrzewała"27. W drugim tekście Sobór traktuje bezpośrednio o rozwoju miłości małżeńskiej, którego naturalnie nie sposób nie utożsamiać z rodzicielstwem ani z dobrem małżonków jako celami małżeństwa. Owa miłość, która stanowi właściwą relację pary małżeńskiej, która jest jednością dwojga, kieruje ich z samej natury na wzajemną pomoc i dobro małżonków ${ }^{28}$.

\section{Akt małżeński w realizacji dobra małżonków}

Mężczyzna i kobieta odczytujący prawdę o miłości małżeńskiej odkrywają swój związek jako niesamowity i szczególny dar od Boga oraz jednocześnie potrafią odkryć, że współżycie seksualne jest darem właśnie od Niego. W czasie aktu małżeńskiego może dojść do spotkania ze współmałżonkiem i Bogiem. Jeżeli tak jest, przed małżonkami odsłaniają się nowe horyzonty miłości. Dzieje się z nimi coś niezwykłego,

25 Por. A. Sarmiento, Małżeństwo chrześcijańskie..., dz. cyt., s. 340.

$26 \mathrm{KDK} 48$.

27 KDK 50.

28 Por. A. Sarmiento, Malżeństwo chrześcijańskie..., dz. cyt., s. 341. 
bo odkrywają, że oboje są nierozerwalnie związani ze sobą tajemnicą, która się przed nimi odsłoniła ${ }^{29}$. Miłość małżeńska wyrażająca się we wzajemnym współżyciu cielesnym nie jest w małżeństwie wszystkim, mimo że jest częścią decydującą. Jest w pewnym sensie centrum życia małżonków. Z tą miłością nierozerwalnie związane jest doskonalenie się, obopólne dobro małżonków. Objawia się to jako wewnętrzna zasada, trwała moc i cel ostateczny ${ }^{30}$. „Miłość wyraża się i też dopełnia w szczególny sposób właściwym aktem małżeńskim”³1.

Akt małżeński jest aktem właściwym i specyficznym dla małżeństwa. Można go określić terminami takimi jak zjednoczenie seksualne, obcowanie małżeńskie. Może zostać opisany jako spotkanie mężczyzny i kobiety w małżeństwie. Jest też prawidłowo ukierunkowanym sposobem, dzięki któremu małżonkowie wyrażają się jako jedno ciało i poznają siebie w swej specyficznej kondycji jako małżonków. Akt ten jest nie tylko etycznie prawy, dobry i nie zaciąga żadnej grzeszności, ale w określonych sytuacjach i warunkach jest źródłem uświęcenia. Współżycie małżeńskie jest zawsze godne, gdy jest dowodem prawdziwej miłości i dzięki tej miłości jest otwarte na płodność i potomstwo.

Akt seksualny w małżeństwie jest także sposobem wyrażania więzi małżeńskiej oraz sposobem komunikacji, która obejmuje przeróżne formy ekspresji ciała ${ }^{32}$. Natomiast w niechrześcijańskiej mentalności

29 Por. K. Więsyk, K. Wojaczek, Urzeczywistnienie się Kościoła w małżeństwie rodzinie, [w:] Matżeństwo i rodzina w świetle nauki i wspótczesnej teologii, red.

A. L. Szafrański, Lublin 1985, s. 201-238.

30 FC 18.

31 KDK 49.

32 Por. K. Knotz, Akt małżeński - szansa spotkania z Bogiem, Kraków 2001, s. $158-159$. 
ten akt kojarzy się z czynnością biologiczną, zmysłową czy popędową. Z tego względu jest rzeczą wskazaną, aby jasno zaznaczyć, że Bóg przychodzi do małżonków nie w samym akcie seksualnym rozumianym jako zbliżenie się ich ciał, ale w więzi, która poprzez ten akt się wytworzyła i się wyraża. Więź jest jednocześnie duchowa, psychiczna i fizyczna. To tu w pełni małżeńskiego spotkania dochodzi do tego, że akt małżeński łączy najściślejszą więzią męża i żonę33. Wszystko więc, co w małżeństwie wyraża również akt seksualny, urzeczywistnia i uobecnia w sposób widzialny i wprost namacalny ich miłosną więź, ale też może być uświęcające, sakramentalne ${ }^{34}$.

Akt seksualny jest święty, bo stanowi akt małżeński i zostaje objęty gwarancją obecności ze strony Boga ${ }^{35}$. Tylko grzech może zniszczyć świętość aktu małżeńskiego. Jest on znakiem przymierza z Bogiem i małżonkiem tylko wtedy, gdy wyraża prawdę tego przymierza. Prawdziwa miłość, która zostaje wyrażona w akcie seksualnym wymaga nierozerwalności i wierności, bo jest darem z siebie samego czynionym drugiemu dla jego dobra; umie uszanować osobowość i wolność drugiego; nie jest egoistyczna, nie szuka samego siebie w drugim, jest ofiarna, nie władcza ${ }^{36}$. Małżonkowie o tyle osiągną doskonałość i dobro, do którego są przeznaczeni, o ile cele małżeństwa zostaną odpowiednio uporządkowane, niosąc za sobą osiągnięcie

33 Por. K. Wojaczek, Sakramentalność małżeństwa jako podstawa organizacji duszpasterstwa małżeństw, „Roczniki Teologiczno-Kanoniczne” 37 (1990) nr 6, s. 23.

34 Por. J. Grześkowiak, Misterium matżeństwa, Poznań 1996, s. 73.

35 Por. L. Christenson, Rodzina chrześcijańska, przeł. I. Doleżal-Nowicka, Warszawa 1988, s. 26.

36 Por. Kongregacja do Spraw Wychowania Katolickiego, Wytyczne wychowawcze w odniesieniu do ludzkiej miłości, Rzym 1983, 94. 
własnego dobra. Tylko wtedy akt małżeński będzie służyć realizacji dobra małżonków, jeżeli zachowując owo uporządkowanie celów w związku, pozostaje prawdziwie małżeński. Dzieje się tak jedynie wtedy, gdy małżeńska relacja seksualna jest wyrazem wzajemnego daru, który zawiera dość istotne elementy. Są to między innymi: postawa otwarcia na ojcostwo i macierzyństwo (gdyby jej nie było, nie byłoby afirmacji współmałżonka jako osoby, nie byłoby daru z siebie oraz nie byłoby wzajemnego dzielenia życia), szacunek dla osoby innego (unikanie traktowania drugiej strony za przedmiot użycia, zaspokojenia i przyjemności), opanowanie własnych instynktów (wolność konieczna do oddania siebie drugiemu jest możliwa do osiągnięcia, gdy nie jest się niewolnikiem pragnień seksualnych). Do spełnienia aktu seksualnego tak, aby był małżeńskim, potrzeba, aby małżonkowie spełnili pewne warunki. Ważne, aby realizowane $\mathrm{w}$ tej materii działanie było dobre samo w sobie ${ }^{37}$.

Pierwszym warunek jest spełniony, gdy małżonkowie nie sprzeciwiają się celowości i znaczeniom wpisanym w naturę aktu małżeńskiego, tzn. gdy respektują wymiar rodzicielski swego połączenia w jedno ciało. Ważne jest, że małżonkowie, będąc zjednoczonymi, świadomie nie wchodzili w relację jako zwykłe przedmioty podczas spotkania seksualnego. Dlatego istotne jest uważne spojrzenie na dobro drugiego w realizacji aktu seksualnego. Następnym warunkiem oprócz prawego celu jest brak sprzeciwu wobec natury aktu małżeńskiego. Ten akt powinien być urzeczywistniany w odpowiedni sposób, w sprzyjających temu celowi okolicznościach, naznaczonych szacunkiem i miłością. Okoliczności mogą być związane

37 Por. A. Sarmiento, Małżeństwo chrześcijańskie..., dz. cyt., s. 346-347. 
z osobą, sposobem, czasem. W trzecim warunku akt małżeński, aby był zasługujący, jest potrzeba stanu łaski u tych, którzy ten akt realizują ${ }^{38}$.

\section{Ukierunkowanie małżeństwa na przekazywanie życia}

Przymiotem małżeństwa jest płodność. Jest to szczególnie widoczne na płaszczyźnie rozumu i doświadczenia, ale tylko wtedy, kiedy małżeństwo jest ujmowane jako naturalny związek i nierozerwalna wspólnota osób. Małżonkowie są obdarzeni wyjątkowym darem, jakim jest budzenie nowego życia, a jednocześnie mają udział w twórczym działaniu Boga. Nade wszystko małżonkowie ponoszą wielką odpowiedzialność za misję przekazywania życia przed Bogiem, własnym sumieniem i społeczeństwem, w którym egzystują ${ }^{39}$. Z samej zaś swojej natury instytucja małżeństwa oraz miłość małżeńska nastawione są na rodzenie i wychowanie potomstwa, co stanowi jej jakby szczytowe uwieńczenie ${ }^{40}$.

Jednym z celów małżeństwa jest rodzicielstwo, co równa się stwierdzeniu, że ze swej natury każde małżeństwo jest ukierunkowane na przekazywanie życia. Małżeństwo opiera się na podwójnej celowości: dobra małżonków i otwarcia na płodność, ze względu na dar istnienia jako podstawowe dobro osoby. Cele te są nierozdzielne. Jednak swoistą wartością małżeństwa jest to, że jest ono ukierunkowane na danie początku życia nowej osobie ludzkiej. Wartość ta wzrośnie tylko wtedy, kiedy własną seksualność będzie

38 Por. A. Sarmiento, Małżeństwo chrześcijańskie..., dz. cyt., s. 347-348.

39 Por. A. Kokoszka, Moralność życia małżeńskiego, dz. cyt., s. 161.

40 Por. KDK 50. 
można pojmować jako współudział w Bożym stwarzaniu ludzkiej istoty jako połączenia Bożej i ludzkiej miłości. „Jeżeli zatem zostaną zachowane te dwa istotne aspekty stosunku małżeńskiego, jednoczący i prokreacyjny, to wtedy zachowuje on w pełni swoje znaczenie wzajemnej i prawdziwej miłości oraz swoje odniesienie do bardzo wzniosłego powołania do rodzicielstwa"41. Przekazywanie życia jest obowiązkiem i główną misją małżonków, którzy są współpracownikami miłości Boga Stwórcy i jakby jej wyrazicielami ${ }^{42}$. Płodność jest darem, który objawia się jako jeden z podstawowych celów małżeństwa, ponieważ miłość małżeńska zmierza ze swojej natury do tego, aby być płodną. To dziecko jako owoc miłości małżeńskiej wyłania się w samym centrum tego wzajemnego daru, którego jest wypełnieniem ${ }^{43}$. „Tak więc podstawowym zadaniem rodziny jest służba życiu, urzeczywistnianie $\mathrm{w}$ ciągu dziejów pierwotnego błogosławieństwa Stwórcy: przekazywania życia - poprzez rodzenie - obrazu Bożego z człowieka na człowieka"44. Małżeństwo to świadomość swoich obowiązków i zadań połączone ze szczególną wyjątkową odpowiedzialnością. Istotne jest zaakceptowanie płodnego charakteru współżycia seksualnego, które jest jednocześnie wyrazem woli samego Stwórcy ${ }^{45}$. Małżeństwo jest ukierunkowane na rodzicielstwo, bo seksualność jest podporządkowana małżeństwu, a ono samo w sobie przekazywaniu i wychowywaniu życia. To ukierunkowanie na płodność jest tak istotne,

41 Paweł VI, Encyklika Humanae vitae [dalej: HV], 12.

42 Por. KDK 50.

43 Por. KKK 2366.

44 FC 28.

45 A. Kokoszka, Moralność życia matżeńskiego, dz. cyt., s. 162. 
że respektowanie tego jest konieczne dla egzystencji małżeństwa. Jednak mimo to małżeństwa bezdzietne i samo życie małżeńskie nie tracą na wartości, jeżeli tylko małżonkowie respektują naturalną dyspozycję na płodność, która jest właściwa miłości małżeńskiej. Małżeństwo nie jest ustanowione tylko dla rodzenia potomstwa, ale sama natura nierozerwalnego związku między dwiema osobami i dobro potomstwa wymagaja, aby wzajemna miłość małżonków w odpowiedni sposób wyrażała się po to, by się rozwijać i dojrzewać. Dlatego małżeństwo trwa jako połączenie i wspólnota całego życia oraz zachowuje swoją wartość i nierozerwalność nawet wtedy, kiedy brakuje upragnionego potomstwa ${ }^{46}$.

Współżycie seksualne i zrodzenie potomstwa ukazane jest w Księdze Rodzaju jako szczególna realizacja woli Stwórcy. Słowo Boga Ojca skierowane do pierwszej pary ludzkiej: „Bądźcie płodni i rozmnażajcie się, abyście zaludnili ziemię i uczynili ją sobie poddaną” (Rdz 1, 28) jest wypełniane od razu przez pierwszych małżonków. Człowiek współżył ze swoją żoną Ewą, a ta poczęła i urodziłaa ${ }^{47}$. Ten opis stawia nas w całej realności zjednoczenia małżeńskiego, tego współżycia, gdzie mężczyzna i kobieta stają się jednym ciałem ${ }^{48}$. Małżonkowie, którzy planują zbliżenie seksualne, odczuwają siłę dynamizmu, jakim jest płodność, gdyż ich świadomość przenika myśl, że może się począć nowe życie. Właśnie myśl o dziecku, o możliwym poczęciu jest podobna do katalizatora, który ujawnia duchowy świat małżonków, ich hierarchię wartości, podejście do życia, stopień

\footnotetext{
46 Por. KDK 50.

47 Por. Synowiec, Na początku, Warszawa 1989, s. 203.

48 Por. Jan Pawel II, Mężczyzną i niewiasta stworzyt ich. Chrystus odwołuje sie do początku, Lublin 1982, s. 70.
} 
odpowiedzialności za drugiego człowieka, poświęcenie, a nawet ofiarność. Ta myśl jest wskaźnikiem jakości miłości małżeńskiej. Odkrycie tego typu stanów, objawiających się w emocjach, uczuciach, zachowaniach i postawach, poszerza pole świadomości przez stopniowe odkrywanie treści dotychczas niepoznanych, które nie były świadome ${ }^{49}$. Gotowość do przyjęcia dziecka i otwartość na nie oraz pragnienie jego urodzenia jest wyrazem pogodnego, radosnego i promieniującego szczęścia. Natomiast negatywne podejście do dziecka, zamknięcie się na akt małżeński przejawia się agresją, niechęcią, egoizmem, brakiem tolerancji, a co chyba najważniejsze chęcią bezwzględnego panowania nad istotą słabszą i uzależnioną od nich, aż do posuniętego do odmowy prawa do życia, nie mówiąc już o rozwoju $u^{50}$.

Płodność jest energią nie tylko fizyczną, ale również duchową i psychiczną, która w odpowiednich warunkach ukazuje swoją twórczą moc. Płodność ujawnia się jako stała dyspozycja do pogłębiania się jedności między małżonkami jako kochającymi się osobami. Wyraża się w zdolności do twórczego budowania duchowej, intelektualnej i emocjonalnej więzi. Jednocześnie uzdalnia do bliskiego i głębokiego kontaktu z Bogiem i współmałżonkiem. Człowiek w tym momencie składa siebie jako dar dla drugiego ${ }^{51}$. Czysta miłość i jej witalność jest bezpośrednio związana $\mathrm{z}$ energią owej płodności. Ta płodność jest wewnętrznym wymiarem czystej miłości ${ }^{52}$.

49 Por. K. Knotz, Akt małżénski..., dz. cyt., s. 224.

50 Por. M. Schooyans, Aborcja a polityka, przekł. K. Deryło, Lublin 1991, s. 138.

51 Por. K. Knotz, Akt małżeński..., dz. cyt., s. 228-229.

52 Por. J. Bajda, Akt małżeński w nauczaniu Kościoła, „Chrześcijanin w Świecie” 162 (1987) nr 3, s. 41. 
W akt małżeński wpisane są dwa znaczenia, które odpowiadają podwójnej celowości małżeństwa, mianowicie jednoczące małżonków i prokreacyjne. Nierozdzielność tych dóbr w relacji małżeńskiej jest podyktowana przez prawdę o akcie małżeńskim jako akcie miłości małżonków określanym jako charakter wymiaru jednoczącego i prokreacyjnego ludzkiej seksualności. Implikują się wzajemnie do tego stopnia, że nie mogą bez siebie istnieć, bo ani korzystanie z seksualności nie jest ludzkie, ani zjednoczenie seksualne nie jest prawdziwie małżeńskie ${ }^{53}$.

Związek małżeński budowany na miłości jest skierowany na jedność, która objawia się jako najściślejsza wspólnota życia na ziemi. Nie usuwa jednak osobowych różnic pomiędzy małżonkami. Ta jedność polega na wzajemnym uzupełnianiu się, ponieważ inne są zadania każdej ze stron, równa jednak ich wspólna odpowiedzialność za dobro małżeństwa, małżonków, szczególnie za wzajemną miłość, za jej pielęgnowanie i rozwijanie. U podstaw kształtowania jedności we wzajemnym współżyciu małżeńskim jest pełne uznanie równości praw i obowiązków małżonków, a nade wszystko równej godności obu stron ${ }^{54}$. Małżonkowie, którzy kroczą odpowiedzialną drogą życia, osiągają stabilność i harmonię swojego związku. Narasta w nich wewnętrzny pokój, zaufanie oraz wzajemny szacunek ${ }^{55}$. W takim wypadku ich miłość coraz bardziej odzwierciedla płodną miłość Chrystusa do Kościoła ${ }^{56}$. Jest to proces, który można określić

53 Por. A. Sarmiento, Małżeństwo chrześcijańskie..., dz. cyt., s. 364.

54 KDK 49.

55 Por. K. Knotz, Akt matżeński..., dz. cyt., s. 230.

56 Por. K. Wojaczek, Sakramentalno-eklezjologiczne podstawy katolickiej koncepcji matżeństwa, „Collectanea Theologica” 68 (1998) nr 4, s. 31-53. 
jako ukierunkowanie energii, jaką jest miłość. Ta koncentracja ujawnia się w sposób rzeczywisty we wzroście jedności pomiędzy małżonkami. Wtedy stają się naprawdę jednym ciałem ${ }^{57}$.

Stosunki w małżeństwie są czymś zwykłym, zrozumiałym i koniecznym, ale również $\mathrm{w}$ pełni godnym i szlachetnym. Współżycie cielesne stawia jednak małżonków przed jego naturalną celowością i szczególnie istotnym ukierunkowaniem na rodzicielstwo, czyli płodnośćs ${ }^{5}$. „Z samej zaś natury swojej instytucja małżeństwa oraz miłość małżeńska nastawione są na rodzenie i wychowanie potomstwa, co stanowi ich jakby szczytowe uwieńczenie" ${ }^{59}$. Rodzicielstwo ma ścisły związek z miłością małżonków, ponieważ jest jej bezpośrednim owocem. Miłość małżeńska, uczestnicząc w miłości Boga, dąży ku przekazywaniu życia ${ }^{60}$. Rodzicielstwo, które ujawnia się w płodności miłości małżeńskiej, nie zacieśnia się jednak tylko do fizycznego rodzenia życia. Oprócz tego obejmuje owoce życia moralnego, duchowego, które to rodzice przekazują dzieciom ${ }^{61}$. Ta sama miłość odpowiedzialna w małżeństwie oznacza również odpowiedzialność za owoc miłości małżonków, która prowadzi do odpowiedzialnego rodzicielstwa ${ }^{62}$. Jest to rozpoznanie i podjęcie przez małżonków swojego powołania do przekazywania życia i wychowywania dzieci ze świadomością przed Stwórca, w którego zbawczych planach mężczyzna i kobieta mają udział poprzez

57 Por. K. Knotz, Akt małżéski..., dz. cyt., s. 230.

58 Por. S. Olejnik, Teologia moralna życia społecznego..., dz. cyt., s. 303.

59 KDK 48.

60 Por. J. Troska, Moralność życia ptciowego, matżeńskiego i rodzinnego, Poznań 1994, s. 73.

61 Por. FC 28.

62 Por. J. Troska, Moralność życia płciowego..., dz. cyt., s. 74. 
zawarcie związku małżeńskiego. Odpowiedzialne rodzicielstwo jest to inaczej również świadome kierowanie własną płodnością oraz cały proces wydawania na świat i wychowywania potomstwa. „Płodność jest owocem i znakiem miłości małżeńskiej, żywym świadectwem pełnego, wzajemnego oddania się małżonków"63. Jeżeli będą zachowane te dwa aspekty współżycia małżeńskiego, czyli jednoczący i prokreacyjny, to w takim wypadku zachowuje on pełne znaczenie wzajemnej i prawdziwej miłości, jednocześnie odnosząc się do w pełni odpowiedzialnego rodzicielstwa ${ }^{64}$.

Samo małżeństwo, jak i miłość małżeńska oraz jej akt, są z racji swojej natury i charakteru ukierunkowane na przekazywanie nowego życia. Akt małżeński w swojej istocie doprowadza naturalnie do rodzicielstwa, ojcostwa i macierzyństwa. To wiąże się z odpowiedzialnością ze strony podejmujących takie działania, gdzie dochodzi również zrodzenie nowego człowieka.

Przez przekazywanie życia rodzice realizują pierwotne błogosławieństwo Stwórcy, są współpracownikami miłości Boga Stwórcy i jakby jej wyrazicielami. Płodny charakter ich współżycia seksualnego jest wyrazem woli Stwórcy. Przekazywanie życia to bardzo doniosły obowiązek, dzięki któremu małżonkowie stają się wolnymi i odpowiedzialnymi współuczestnikami w stwórczym działaniu Boga ${ }^{65}$. Mają wypełniać swoje zadanie w poczuciu chrześcijańskiej ludzkiej odpowiedzialności oraz wyrobić sobie słuszny pogląd, uwzględniając swoje dobro, jak również dobro dzieci już narodzonych i jeszcze przewidywanych, licząc się z dobrem wspólnoty

\footnotetext{
63 FC 28.

64 Por. KKK 2369.

65 Por. HV 1.
} 
rodzinnej, społeczeństwa i Kościoła ${ }^{66}$. Od rodziców jako współpracowników miłości Boga Stwórcy wymaga się przy przekazywaniu życia postępowania odpowiedzialnego, które przejawia się w byciu świadomymi kondycji narzędzi w służbie Boga, a jednocześnie współpracującymi w sposób wolny i odpowiedzialny. Dlatego istotne jest poznanie przez małżonków znaczenia i struktury ludzkiej seksualności oraz respektowanie wartości osobowych i etycznych $\mathrm{w}$ ich integralności związanych z seksualnością i małżeństwem poprzez panowanie nad sobą w cnocie czystości ${ }^{67}$. Misja małżeńskiej płodności, oparta na odpowiedzialnym rodzicielstwie, obejmuje płaszczyzny takie, jak: odpowiedzialne macierzyństwo i ojcostwo, znajomość metod naturalnych i umiejętności opanowania popędu seksualnego, rozumne rodzenie potomstwa oraz pokorna służba życiu ${ }^{68}$.

Małżeństwo i miłość małżeńska, mając wewnętrzne ukierunkowanie na płodność, zakładają odpowiedzialne działanie w pożyciu małżeńskim. Para małżeńska jest powołana do takiego postępowania, żeby każdy akt zjednoczenia zachowywał swoje przeznaczenie do przekazywania życia ludzkiego ${ }^{69}$. Według zamysłu Bożego życie w małżeństwie jest podstawą szerszej wspólnoty rodzinnej, bo sama instytucja małżeństwa i miłość małżeńska są ukierunkowane ku rodzeniu i wychowywaniu potomstwa, w którym znajdują swoje uwieńczenie. „Dziecko nie jest czymś należnym, ale jest darem”º.

66 Por. KDK 50.

67 Por. HV 10.

68 Por. W. Gasidło, Z zagadnień etyki małżeńskiej i rodzinnej..., dz. cyt., s. 118.

69 Por. HV 11.

70 KKK 2378. 
Biblijna Ewa mówi: „Otrzymałam mężczyznę od Pana” (Rdz 4, 1). U początku poczęcia każdej ludzkiej istoty znajduje się wraz ze zrodzeniem przez rodziców stworzenie duszy przez Boga. Bóg posługuje się mężczyzną i kobietą jako narzędziami do przekazywania życia. Człowiek odpowiada na wezwanie do istnienia jako jedyne i wyjątkowe ze strony Boga. Rodzenie nowego człowieka jest kontynuacją stworzenia ${ }^{71}$.

Rodzenie dzieci opiera się na płodności. Choć sama płodność może być pojmowana jako zjawisko spontaniczne, to dzietność zakłada podjęcie osobowej decyzji przez małżonków, odpowiedzialnej, wpływającej w ostatecznym wyniku na kształt wspólnoty rodzinnej. Dlatego to w odniesieniu do człowieka mówi się o rodzeniu, a nie płodzeniu, przez co rozumie się, że małżeńska jedność osób staje się w sposób ludzki źródłem życia. Dzietność wyraża prawdę spełnionego rodzicielstwa, a rodzicielstwo w tej sytuacji oznacza nic innego, jak wewnętrzną postawę gotowości podjęcia misji przekazywania życia oraz odpowiedzialny sposób jej wypełnienia ${ }^{72}$. Bóg w sposób harmonijny przygotował warunki do życia każdemu dziecku, poprzez kochających matkę i ojca obdarzając ich jednocześnie potrzebnym do wychowania instynktem macierzyństwa i ojcostwa ${ }^{73}$. Dziecko jest nieustannym świadectwem wzajemnego zespolenia i oddania się rodziców, jest żywą syntezą ojca i matki ${ }^{74}$.

71 Por. A. Sarmiento, Małżeństwo chrześcijańskie..., dz. cyt., s. 385-386.

72 Por. J. Bajda, Wprowadzenie do teologii dzietności, „Chrześcijanin w Świecie” 71 (1978), s. 65.

73 Por. Przygotowanie do matżeństwa, dz. cyt., s. 251.

74 Por. FC 14. 


\section{Wychowanie dzieci jako cel małżeństwa}

Cel małżeństwa, który przejawia się w służbie życiu, odnosi się do przekazywania jak i wychowania potomstwa, którym mężczyznęi kobietę Pan Bóg obdarzy. Z tego wynika, że podstawowym zadaniem rodziny jest służba życiu' ${ }^{75}$. Kontynuacją rodzicielstwa, niejako przedłużeniem i swoistym wyrazem prokreacji jest wychowanie potomstwa, dbałość o jego rozwój fizyczny, psychiczny oraz duchowo-religijny.

Płodność miłości małżeńskiej nie ogranicza się jedynie do przekazania życia dzieciom, ale obejmuje również ich wychowanie moralne i formację duchową. Jest to odpowiedzialnym zadaniem rodziców. To właśnie rodzice, którzy brali udział we współtworzeniu nowego człowieka, mają pierwszorzędne i niezbywalne prawo oraz obowiązek wychowania ${ }^{76}$. Małżeństwo zostało ustanowione głównie dla dobra potomstwa, nie tylko dla jego urodzenia (bo to jest możliwe również bez małżeństwa), ale po to, aby dzieci jak najlepiej wychować. Jest tak, ponieważ człowiek nie rodzi się skończony. Aby żyć i dochodzić do pełni, do której każda osoba jest powołana, wymagana jest troska od pierwszej chwili jego egzystencji. Dziecko ma prawo do wszelkiej odpowiedzialnej pomocy ze strony rodziców. Wychowanie to inaczej pomaganie za pomocą odpowiednich środków we wzroście i rozwoju dziecka ku doskonałości - zarówno w sferze ciała, jak w sferze ducha. Dziecko jako osoba ludzka ma szczególne prawo do wychowania ze względu na swe człowieczeństwo. Nie można w pełni uzyskać uczłowieczenia bez wychowania ${ }^{77}$. Obowią-

75 Por. FC 28.

76 Por. KKK 2221.

77 Por. Przygotowanie do matżeństwa, dz. cyt., s. 252. 
zek należytego wychowania dzieci jest wpisany w powołanie obojga rodziców, mimo że ich rola wychowawcza jest inna i zmienia się w zależności od wieku i stopnia rozwoju dziecka. Obowiązek wychowania dziecka obejmuje również wychowanie religijne i moralne. Chodzi tu o budzenie pragnienia obcowania z Bogiem i kierowania się w życiu dziecka, a potem dojrzałego człowieka, jego wolą. Jest to szczególnie odpowiedzialne zadanie dla rodziców wychowujących dzieci.

Misja wychowawcza rodziców przyjmuje ten specyficzny kierunek za sprawą sakramentu małżeństwa. To jest konsekwencją relacji, jaka przez chrzest istnieje między małżeństwem a sakramentem. Prawo i obowiązek rodziców względem nowego człowieka połączone z sakramentem małżeństwa są związane z wychowaniem dzieci i są te same i nowe w stosunku do tych, którzy nie zawarli związku sakramentalnego. Te same dlatego, że prawo i obowiązek opiera się na funkcji rodzicielskiej, a nowy, ponieważ dzięki sakramentowi współpraca w przekazywaniu życia ludzkiego jest współpracą w budowaniu i rozszerzaniu królestwa Bożego ${ }^{78}$. Przez zawarcie sakramentu małżeństwa rodzice chrześcijańscy uczestniczą we władzy i miłości samego Boga Ojca i Chrystusa, który jest Pasterzem, a także w macierzyńskiej miłości Kościoła ${ }^{79}$. W pierwotnym wzorze ojcostwa i macierzyństwa rodzice odkrywają naturę i cechy, które kształtują miłość, jaką otaczają swe dzieci. Tę miłość, która ma być normą i duszą inspirującą działanie, realizacją owego prawa - obowiązku w stosunku do potomstwa ${ }^{80}$.

78 Por. A. Sarmiento, Małżeństwo chrześcijańskie..., dz. cyt., s. 404.

79 Por. FC 38.

80 Por. FC 36. 
Wychowanie dzieci jest prawem i obowiązkiem, które opierają się na ich miłości ojcowskiej i macierzyńskiej, które powinny zawsze inspirować troskę dbałości o dzieci. Prawo i obowiązek wychowania są podstawowymi i istotnymi oraz niezastąpionymi i niezbywalnymi elementami każdego dojrzałego małżeństwa. Istotnymi, ponieważ taka jest misja rodzicielska rodziców. Jest to sposób na zapewnienie dzieciom harmonijnego wychowania, zapewnienia klimatu czułości i bezpieczeństwa, jaki rodzice mogą stworzyć, darząc się wzajemną miłością. Zaniedbanie tego sprawiłoby nierozwinięcie ojcostwa i macierzyństwa przynajmniej w wymiarze wychowawczym. Podstawowym $\mathrm{i}$ istotnym elementem jest $\mathrm{w}$ wymiarze przedłużenia życia rodziców. Tu rodzice żyją w dzieciach. Natomiast niezastąpionym i niezbywalnym jest wtedy, kiedy rodzice mogą w wychowaniu swych pociech korzystać z pomocy innych ludzi. Pomoc zewnętrzna może się zaczynać od pierwszorzędnej i pierwotnej roli rodziców, a potem można dostarczyć środki konieczne dla wypełnienia tego prawa-obowiązku ${ }^{81}$.

Ostatecznym celem wychowania jest to, aby dzieci rozwijały się w taki sposób, by mogły odnaleźć własną tożsamość i osiągnąć to, do czego są wezwane poprzez swoje powołanie, jakim obdarzył je Bóg. Ważne jest towarzyszenie i pomoc, zwłaszcza w dzieciństwie i okresie dorastania. Pełne i integralne wychowanie dzieci wymaga solidnej dbałości na wielu płaszczyznach życia: materialnym, duchowym, naturalnym i nadprzyrodzonym. Wychowanie dotyczy dwóch fundamentalnych wymiarów osoby: godności osobowej i socjalizacji, a u chrześcijan dochodzi jeszcze płaszczyzna nadprzyrodzona ${ }^{82}$.

81 Por. A. Sarmiento, Matżeństwo chrześcijańskie..., dz. cyt., s. 406-407.

82 Por. A. Sarmiento, Małżeństwo chrześcijańskie..., dz. cyt., s. 407. 
Rodzice jako pierwsi są odpowiedzialni za wychowanie potomstwa. Wymaga to nauczenia się wyrzeczenia, zdrowego osądu, panowania nad sobą, które są podstawą wszelkiej i prawdziwej wolności. Wolność jest jedną z podstawowych wartości w wychowaniu dzieci, bo tylko dzięki prawemu korzystaniu z wolności, jaką zostały obdarzone, mogą osiągnąć pełnię ludzką i nadprzyrodzoną. Jest to nieodzowny element wychowania. Jednocześnie wychowanie do wolności ma być wychowaniem cnót, a celem cnót jest pomoc człowiekowi w używaniu i wchodzeniu w relację z tym, co jest stworzone w sposób wolny, czyli odpowiadający naturze dóbr, ale i człowieka. To rodzice są po to, aby uczyć dzieci podporządkowywać wymiary materialne i instynktowne wymiarom duchowym i wewnętrznym ${ }^{83}$.

Dom rodzinny jest naturalnym środowiskiem uczenia dzieci odpowiedzialności za wspólnotę rodzinną, w której się znajdują, i solidarności z nią. Rodzice ukierunkowują swoje dzieci, aby unikały fałszywych ustępstw i poniżania się, które są pewnym zagrożeniem dla społeczności ludzkiej ${ }^{84}$. $Z$ tego to powodu rodzina jest najmniejszą komórką społeczną oraz jest szkołą humanizacji człowieka i społeczeństwa. Dzieci nie mogą się rozwijać, nie wchodząc w relacje osobowe z innymi ludźmi ${ }^{85}$. Osoba ludzka jest istotą społeczną. Nie jest to coś dodanego, ale jest wymagane przez naturę. To przez wymianę poglądów, doświadczeń, dialog z innymi człowiek może się rozwijać i odpowiadać na swoje powołanie ${ }^{86}$. Jednak do realizacji tych zadań służą jedynie te relacje, które opierają się na szczero-

83 Por. KKK 2223.

84 Por. KKK 2224.

85 Por. KDK 12.

86 Por. KKK 1879. 
ści i prawdzie, czyli te, które odpowiadają poczuciu prawdziwej sprawiedliwości, która to prowadzi do poszanowania godności osobistej każdego człowieka ${ }^{87}$. Jest to powodem, by wychowanie w poczuciu prawdziwej sprawiedliwości przyporządkować drugiej istotnej wartości wychowania. Tylko w taki sposób rodzina będzie szkołą człowieczeństwa. Jednak sprawiedliwa relacja z innymi decyduje się w ostateczności w miłości, a co za tym idzie wychowaniu do czystości. Tego wychowania nie sposób oddzielić od wychowania w pozostałych cnotach ${ }^{88}$. Wychowanie do czystości niesie za sobą jednocześnie wychowanie do odpowiedniego podejścia do spraw seksualności. Wychowanie seksualne nie może być sprowadzone wyłącznie na tory teoretyczne. Tak samo sama fizjologia nie może rościć sobie pretensji do wyjaśniania bez reszty miłości seksualną pomiędzy mężczyzną a kobietą ${ }^{89}$. Wychowanie seksualne jest sprawą wielkiej wagi. Rodzice pełnią wyjątkową rolę w wychowaniu swoich dzieci w tej dziedzinie. W tym działaniu nikt nie może ich wyręczyć, ale Kościół czy szkoła mogą rodzicom w tym pomóc. Zasady w wychowaniu seksualnym są bardzo istotne, ponieważ każde dziecko jest jedyną i niepowtarzalną osobą i dlatego otrzymuje przystosowane dla niego informacje. Wychowanie w czystości i odpowiednie informacje o seksualności najlepiej, jeżeli są podawane w szerszym kontekście wychowania do miłości ${ }^{90}$.

87 Por. FC 37.

88 Por. A. Sarmiento, Małżéstwo chrześcijańskie..., dz. cyt., s. 410.

89 Por. K. Wojtyła, Propedeutyka sakramentu małżéstwa, „Ateneum Kapłańskie" 50 (1958), s. 31.

90 Por. Papieska Rada ds. rodziny, Ludzka płciowość: prawda i znaczenie. Wskazania dla wychowania w rodzinie, [w:] Posoborowe dokumenty Kościoła Katolickiego o matżeństwie i rodzinie, Kraków 1991, t. 2, s. 65-76. 
„Przez łaskę sakramentu małżeństwa rodzice otrzymali zadanie i przywilej ewangelizowania swoich dzieci. Możliwie jak najwcześniej powinni wprowadzać swoje dzieci w tajemnicę wiary, której są dla nich pierwszymi zwiastunami"'1 . Dobrze, jeśli rodzice od wczesnego dzieciństwa włączają swoje dzieci w życie Kościoła. Taki styl rozwija zdolność do miłości, która na całe życie pozostanie autentycznym początkiem i podporą wiary ${ }^{92}$. Na kanwie formacji i wychowania ludzkiego łaska nie niszczy natury, ale to wychowanie chrześcijańskie dostosowane do etapów rozwoju dzieci zawiera w sobie włączenie dzieci do życia sakramentalnego oraz wychowanie w wierze. Jednak ostatecznym celem wychowania jest sprawowanie takiego wychowania, aby dzieci postępowały jak prawdziwi chrześcijanie ${ }^{93}$.

\section{Podsumowanie}

Małżeństwo chrześcijańskie między mężczyzną a kobietą w pełni realizuje się w miłości, która między nimi zachodzi. To miłość jako nadrzędna moc koordynuje działania osób, męża i żony w zakresie celów małżeństwa. Ta miłość niesie ze sobą prawidłową koordynację tych celów, według których w tradycyjnym nauczaniu Kościoła kształtuje się ład moralny życia małżeńskiego.

91 Sobór Watykański II, Konstytucja Lumen gentium, 11.

92 Por. KKK 2225.

93 Por. A. Sarmiento, Małżeństwo chrześcijańskie..., dz. cyt., s. 411.

Marek Kluz, Artur Sylwester Słomka, Małżenstwo jako wyraz petnej realizacji mitości między mężczyzną a kobieta, [w:] Rodzina między praca a ptacą. Refleksja nad społeczna myśla encykliki Laborem exercens Jana Pawła II, red. Robert Kantor, Marek Kluz, Józef Młyński, Kraków 2016, s. 273-300.

DOI: http://dx.doi.org/10.15633/9788374385015.15 